\title{
Perkembangan Awal Protocorm Anggrek Phalaenopsis amabilis secara In Vitro setelah Penambahan Zat Pengatur Tumbuh a-Naphtaleneacetic Acid dan Thidiazuron
}

\author{
Eka Fitriana Candra Ningrum ${ }^{1}$, Ikhsanudin Nur Rosyidi ${ }^{1}$, Rizka Riliant Puspasari ${ }^{1}$ dan Endang Semiarti ${ }^{1}$ \\ ${ }^{1}$ Fakultas Biologi, Universitas Gadjah Mada Yogyakarta \\ Email : ikhsanudin.nur.r@mail.ugm.ac.id
}

\begin{abstract}
Phalaenopsis amabilis (L.) Blume is one of nature orchids with a high commercial value. The orchid cultivation is difficult because the seeds are microscopic and don't have the endosperm, so it needs to be done with in vitro culture. This cultivation need medium that supports the growth of the orchids for example with the addition kind of plant growth regulator that is auxin and cytokinin. This study was aimed determining effect of the plant growth regulator of early development of $P$. amabilis orchid protocorm in vitro aspects of morphology and anatomy. Then protocorm sub cultured on medium with NAA and TDZ combinations at various concentrations and incubated in a room temperature. Protocorm orchid is then observed for 2 weeks which includes the percentage of growth, percentage protocorm the forming buds and absorbing hair. Making the anatomical preparations made by taking protocorm every week, stored in $70 \%$ alcohol solution and made preparations anatomy using Parafin method with safranin staining. The results showed the addition of NAA and TDZ protocorm growth reached $100 \%$. The protocorm percentage of the forming buds as follows (0: $0,0: 0.2,0.5: 0,0.5: 0.2,1: 0$ and $1: 0.2)$ ppm was $24 \%, 22 \%, 32 \%$, $40 \%, 40 \%$ and $38 \%$ while the protocorm observed which form absorbing hair included 10\%, 18\%, $14 \%, 24 \%, 16 \%$ and $0 \%$. The cell diameter ranged from $39.2 \pm 0.47 \mu \mathrm{m}, 0.97 \mu \mathrm{m} \pm 44.4,39.08 \pm 0.5 \mu \mathrm{m}, 0.2 \mu \mathrm{m} \pm 38.83,39.5 \pm 0.39 \mu \mathrm{m}$ and $39.75 \pm 0.28 \mu \mathrm{m}$. Therefore we can conclude that the most optimal medium in $P$. amabilis orchid growing in vitro is medium NP with a combination of NAA and TDZ (0.2: 0.5) ppm.
\end{abstract}

Key words : anatomy, in vitro cultivation, morphology, Phalaenopsis amabilis

\begin{abstract}
Abstrak
Phalaenopsis amabilis (L.) Blume merupakan salah satu anggrek alam dengan nilai komersial yang tinggi. Budidaya anggrek ini cukup sulit dilakukan karena biji bersifat mikroskopis dan tidak memiliki endosperm, sehingga perlu dilakukan kultur in vitro. Dalam budidaya ini diperlukan medium pendukung pertumbuhan anggrek secara optimal misalnya dengan penambahan Zat Pengatur Tumbuh (ZPT) dari golongan auksin dan sitokinin. Penelitian ini bertujuan untuk mengetahui pengaruh penambahan ZPT tersebut terhadap perkembangan awal protocorm (pertumbuhan embrio anggrek) $P$. amabilis secara in vitro dari aspek morfologi dan anatomi. Protocorm disubkultur pada medium NP dengan kombinasi ZPT NAA dan TDZ pada berbagai konsentrasi dan diinkubasi pada suhu ruangan. Dilakukan pengamatan selama 2 minggu yang mencakup persentase pertumbuhan, persentase protocorm yang membentuk tunas dan absorbing hair. Pembuatan preparat anatomi dilakukan dengan mengambil protocorm setiap minggunya, disimpan dalam larutan alkohol $70 \%$ dan dibuat preparat anatomi menggunakan metode Parafin dengan pewarnaan safranin. Hasil penelitian menunjukkan pada penambahan NAA dan TDZ pertumbuhan protocorm mencapai 100\%. Persentase protocorm yang membentuk tunas berturut turut $(0: 0,0,2: 0,0: 0,5,0,2: 0,5$, $0: 1$, dan $0,2: 1) \mathrm{ppm}$ adalah $24 \%, 22 \%, 32 \%, 40 \%, 40 \%$ dan $38 \%$ sedangkan untuk pengamatan protocorm yang membentuk absorbing hair sebesar 10\%, 18\%, 14\%, 24\%, 16\%, dan $0 \%$. Untuk diameter sel berukuran $39.2 \pm 0.47 \mu \mathrm{m}, 44.4 \pm 0.97 \mu \mathrm{m}, 39.08 \pm 0.5 \mu \mathrm{m}, 38.83 \pm 0.2 \mu \mathrm{m}, 39.5 \pm 0.39 \mu \mathrm{m}$ dan $39.75 \pm 0.28 \mu \mathrm{m}$. Dapat disimpulkan bahwa medium yang paling optimal dalam pertumbuhan anggrek $P$. amabilis secara in vitro adalah medium NP dengan kombinasi NAA dan TDZ $(0.2: 0.5)$ ppm.
\end{abstract}

Kata kunci : anatomi, kultur in vitro, morfologi, Phalaenopsis amabilis

\section{Pendahuluan}

Salah satu spesies tumbuhan dengan keanekaragaman yang tinggi di Indonesia adalah anggrek. Beberapa jenis anggrek mempunyai nilai komersial yang tinggi karena bentuk bunga yang indah, unik, dapat bertahan tahan lama, tidak mudah layu, dan memiliki waktu mekar yang lama sehingga banyak dicari untuk diperdagangkan (Chugh et al, 2009). Salah satu anggrek yang potensial untuk dikembangkan yaitu Phalaenopsis amabilis, yang ditetapkan sebagai satu dari tiga Bunga Nasional Indonesia. Berdasarkan
Keputusan Presiden No. 4 Tahun 1993, $P$. amabilis disebut sebagai Puspa Pesona Indonesia. Spesies ini memiliki kelopak berwarna putih, bentuk bunga yang eksotis serta bentuk bunga seperti kupu-kupu (Phalaenos) dan bentuk labellum yang khas seperti antena. Hal tersebut menyebabkan $P$. amabilis banyak dipilih sebagai induk silangan untuk menghasilkan hibrida-hibrida unggul terutama anggrek bulan putih di dunia. Namun, popularitas $P$. amabilis sebagai bunga asli Indonesia justru meredup karena keberadaannya di alam semakin sukar dijumpai 
akibat eksploitasi yang berlebihan maupun kerusakan hutan. Kendala pengembangan anggrek ini di Indonesia antara lain terbatasnya bibit unggul, teknologi yang digunakan masih sederhana, dan kurangnya dukungan pemerintah. Oleh karena itu, diperlukan upaya budidaya yang lebih efektif dan efisien untuk meningkatkan produktivitas spesies anggrek ini di alam.

Budidaya yang telah dilakukan para peneliti anggrek adalah kultur jaringan secara in vitro. Kultur jaringan merupakan metode perbanyakan tanaman dengan menggunakan bagian vegetatif tanaman dan ditumbuhkan dalam medium buatan serta dilakukan di tempat steril (Razdan, 2003). Metode ini sebagai alternatif untuk mendapatkan propagasi klon tanaman dalam waktu singkat dan jumlah besar. Kultur in vitro dapat dilakukan dengan 3 cara, yaitu pembentukan tunas adventif, poliferasi tunas lateral dan embriogenesis somatic. Setiap tunas yang dihasilkan dapat dijadikan sebagai sumber eksplan untuk penggandaan tunas selanjutnya sehingga diperoleh tunas yang banyak dalam waktu yang relatif singkat (Kosmiatin et al, 2005).

Faktor-faktor penentu keberhasilan perkecambahan secara in vitro yaitu genotip tanaman, kondisi fisiologis tanaman, jenis dan kondisi medium, lingkungan kultur, dan Zat Pengatur Tumbuh (ZPT) (Zhang et al, 2000). Senyawa-senyawa ZPT memiliki karakteristik yang sama seperti hormon tetapi diproduksisecara eksogen. Pertumbuhan dan morfogenesis secara in vitro diatur oleh hormon tanaman dan hormon eksogen. Pemberian hormon eksogen dapat menaikkan tekanan osmotik, meningkatkan sintesa protein dan permeabilitas sel terhadap air, serta menurunkan tekanan dinding sel sehingga air dapat masuk ke dalam sel dan sel mengalami pertumbuhan (George dan Sherington, 1984). Hormon-hormon yang sering digunakan untuk kultur in vitro adalah auksin dan sitokinin, salah satunya $\alpha$ Naphtaleneacetic Acid (NAA) (Utami et al, 2007; Wijayani et al, 2007) dan Thidiazuron (TDZ) (Feng dan Chen, 2014). NAA merupakan golongan auksin yang berfungsi dalam induksi pemanjangan sel, dormansi apikal, penghambatan pucuk aksilar dan adventif, serta inisiasi pengakaran (Wattimena, 1992). TDZ merupakan golongan sitokinin yang bertugas dalam menstimulasi pembelahan sel dan multiplikasi tunas ketika tahap pembentukan struktur globular dan hati dalam proses embriogenesis (Lu, 1993).

Penelitian perkembangan awal protokorm pada $P$. amabilis sebelumnya pernah dilaporkan. Utami et al (2007) meneliti pengaruh NAA terhadap embriogenesis somatik anggrek bulan. Wijayani et al (2007) menelitin pengaruh NAA dan kinetin terhadap protokorm Grammatophyllum scriptum. Feng dan Chen (2014) meneliti pengaruh TDZ terhadap embriogenesis $P$. aphordite. Quainoo dan Dwomo (2012) meneliti pengaruh kombinasi NAA dan TDZ terhadap berbagai jenis genotip embriogenesis coklat.

Berdasarkan uraian di atas, penelitian ini bertujuan untuk mengetahui pengaruh penambahan kombinasi ZPT TDZ dan NAA secara in vitro terhadap perkembangan morfologi dan anatomi protokorm anggrek $P$. amabilis dan menentukan konsentrasi TDZ dan NAA yang paling optimum untuk meningkatkan pertumbuhan dan perkembangan anggrek $P$. amabilis secara in vitro.

\section{Metode}

Penelitian dilakukan selama dua bulan ( 26 Agustus - 25 September 2016) di Laboratorium Bioteknologi dan Laboratorium Struktur dan Perkembangan Tumbuhan Fakultas Biologi, Universitas Gadjah Mada. Penelitian ini menggunakan protocorm anggrek $P$. amabilis yang telah berumur 2 bulan. Protocorm diperoleh dari Windy Mose peneliti S2 Fakultas Biologi UGM.

Penggunaan medium dalam yang penelitian ini yaitu media NP dengan kombinasi konsentrasi zat pengatur tumbuh NAA dan TDZ. Dicampurkan komponen media NP, sukrosa, dan akuades hingga $500 \mathrm{ml}$ secara berurutan ke dalam erlenmeyer $500 \mathrm{ml}$ dan distirrer sampai sukrosa larut. Medium dibagi rata dan ditambahkan kombinasi konsentrasi zat pengantur tumbuh NAA dan TDZ (Tabel 1). Perlakuan medium diukur pHnya menggunakan indikator universal dan disesuaikan hingga $\mathrm{pH}$ larutan medium 5,2-6 dengan penambahan $\mathrm{KOH} 0,1 \mathrm{~N}$ atau $\mathrm{HCl} 0,1 \mathrm{~N}$. Medium-medium tersebut ditambahkan agar dan dididihkan. Larutan medium disterilisasi menggunakan autoclave $\left(121^{\circ} \mathrm{C} ; 1 \mathrm{~atm}\right)$ selama 15 menit lalu dituang ke dalam petridish steril di dalam LAF dan didiamkan beberapa menit hingga menjendal. Petridish ditutup dengan seal plastic.

Subkultur protocorm anggrek yang telah berumur 2 bulan dilakukan di dalam LAF. Protocorm ditanam dalam perlakuan medium dengan mengatur jarak antar eksplan yang ditanam dan diinkubasikan di dalam ruang inkubator. Pengamatan morfologi dilakukan setiap minggu selama 2 minggu untuk mengetahui pertumbuhan dan perkembangan protocorm anggrek.

Pembuatan preparat anatomi protocorm hasil induksi dengan penambahan kombinasi konsentrasi NAA dan TDZ (Tabel 1) selama 2 minggu menggunakan metode parafin dengan pewarnaan tunggal. Embrio somatik yang telah ditanam dalam perlakuan medium difiksasi dengan larutan FAA selama 24 jam. Embrio dicuci 
berturut-turut dengan alkohol bertingkat mulai dari alkohol (70\%; 80\%; 95\%; 100\% I; 100\% II) masing-masing selama 30 menit. Dealkoholisasi protocorm menggunakan campuran alkohol dan xilol dengan perbandingan 1:3, 1:1, 3:1 masingmasing selama 30 menit. Infiltrasi dilakukan dengan memasukkan embrio somatik ke dalam campuran xilol:parafin (1:9) dengan parafin murni $57^{\circ} \mathrm{C}$ selama $2 \times 24$ jam. Blok parafin dibuat setelah perendaman sampel selama 1 jam dan diiris menggunakan rotary microtom dengan ketebalan $10 \mu \mathrm{m}$. Irisan- direkatkan pada gelas benda yang sudah diolesi dengan campuran gliserin- albumin dan akuades, lalu dipanaskan dalam hot plate. Sebelum dilakukan pewarnaan, dilakukan deparafinisasi dengan cara berturutturut preparat dimasukkan ke dalam xilol II, xilol I, alkohol/xilol (1:3), alkohol/xilol (1:1), alkohol/xilol (3:1), alkohol 100\%, alkohol 100\%, alkohol 95\%, alkohol $80 \%$, dan alkohol 70\%, masing-masing selama 3 menit. Selanjutnya, gelas benda dimasukkan dalam safranin $1 \%$ dalam alkohol $70 \%$ selama 24 jam. Preparat direndam dalam alkohol 70\%, 80\%, 95\%, 100\% I, 100\% II, alkohol/xilol (3:1), alkohol/xilol (1:1), alkohol/xilol (1:3), serta xilol masing-masing selama 1 menit. Preparat ditetesi dengan balsam kanada dan dikeringkan. Preparat diamati dengan menggunakan mikroskop cahaya dan Optilab.

Data yang diperoleh dianalisis secara kualitatif dan kuantitatif untuk mengetahui pengaruh penambahan kombinasi konsentrasi zat pengatur tumbuh NAA dan TDZ (Tabel 1) terhadap pertumbuhan dan perkembangan awal protocorm anggrek $P$. amabilis secara in vitro yang telah berumur 2 bulan. Pengamatan dilakukan selama 2 minggu. Analisis secara morfologi dilakukan dengan melakukan pengamatan ukuran eksplan serta jumlah protocorm yang telah membentuk tunas dan absorbing hair. Kedua pengukuran digunakan untuk menentukan persentase pertumbuhan protocorm anggrek. Analisis secara anatomi dilakukan pengamatan berupa pengukuran panjang sel bagian tengah potongan melintang protocorm.

Tabel 1. Kombinasi Konsentrasi ZPT NAA dan TDZ

\begin{tabular}{clc}
\hline ZPT & \multicolumn{2}{c}{ NAA (ppm) } \\
\cline { 1 - 2 } TDZ $(\mathrm{ppm})$ & \multicolumn{1}{c}{0} & 0,2 \\
0 & $\mathrm{~N}_{0} \mathrm{~T}_{0}$ & $\mathrm{~N}_{0,2} \mathrm{~T}_{0}$ \\
0,5 & $\mathrm{~N}_{0} \mathrm{~T}_{0,5}$ & $\mathrm{~N}_{0,2} \mathrm{~T}_{0,5}$ \\
1 & $\mathrm{~N}_{0} \mathrm{~T}_{1}$ & $\mathrm{~N}_{0,2} \mathrm{~T}_{1}$ \\
\hline
\end{tabular}

Keterangan : NAA = Naptalene Acetic Acid (ppm), TDZ $=$ Thidiazuron (ppm).

\section{Hasil Dan Pembahasan}

Hasil pengamatan morfologi dan anatomi protocorm, diperoleh perubahan morfologi dan anatomi embrio anggrek $\boldsymbol{P}$. amabilis dengan variasi kombinasi konsentrasi NAA dan TDZ (Tabel 3) serta persentase pembentukan tunas dan absorbing hair pada protocorm (Tabel 4). Hasil persentase pertumbuhan tersebut dapat digunakan dalam menentukan konsentrasi NAA dan TDZ yang optimal untuk pertumbuhan embrio anggrek $\boldsymbol{P}$. amabilis.

Tabel 2. Persentase Pertumbuhan Protokorm Anggrek P.amabilis pada medium dengan penambahan kombinasi NAA dan TDZ.

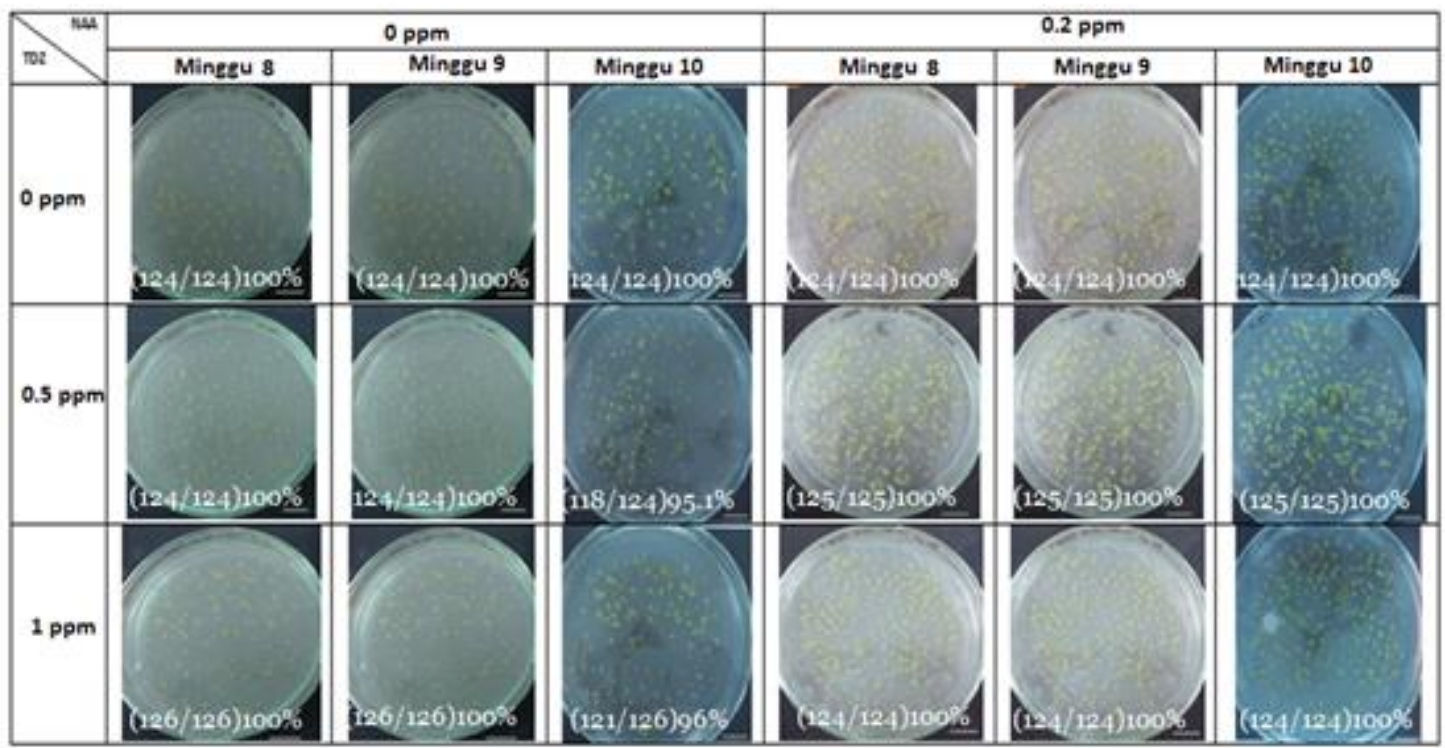

Keterangan : NAA = Naptalene Acetic Acid (ppm), TDZ = Thidiazuron (ppm). 
Tabel 3. Perkembangan Morfologi dan Anatomi Protokorm Anggrek P.ambalis secara In Vitro

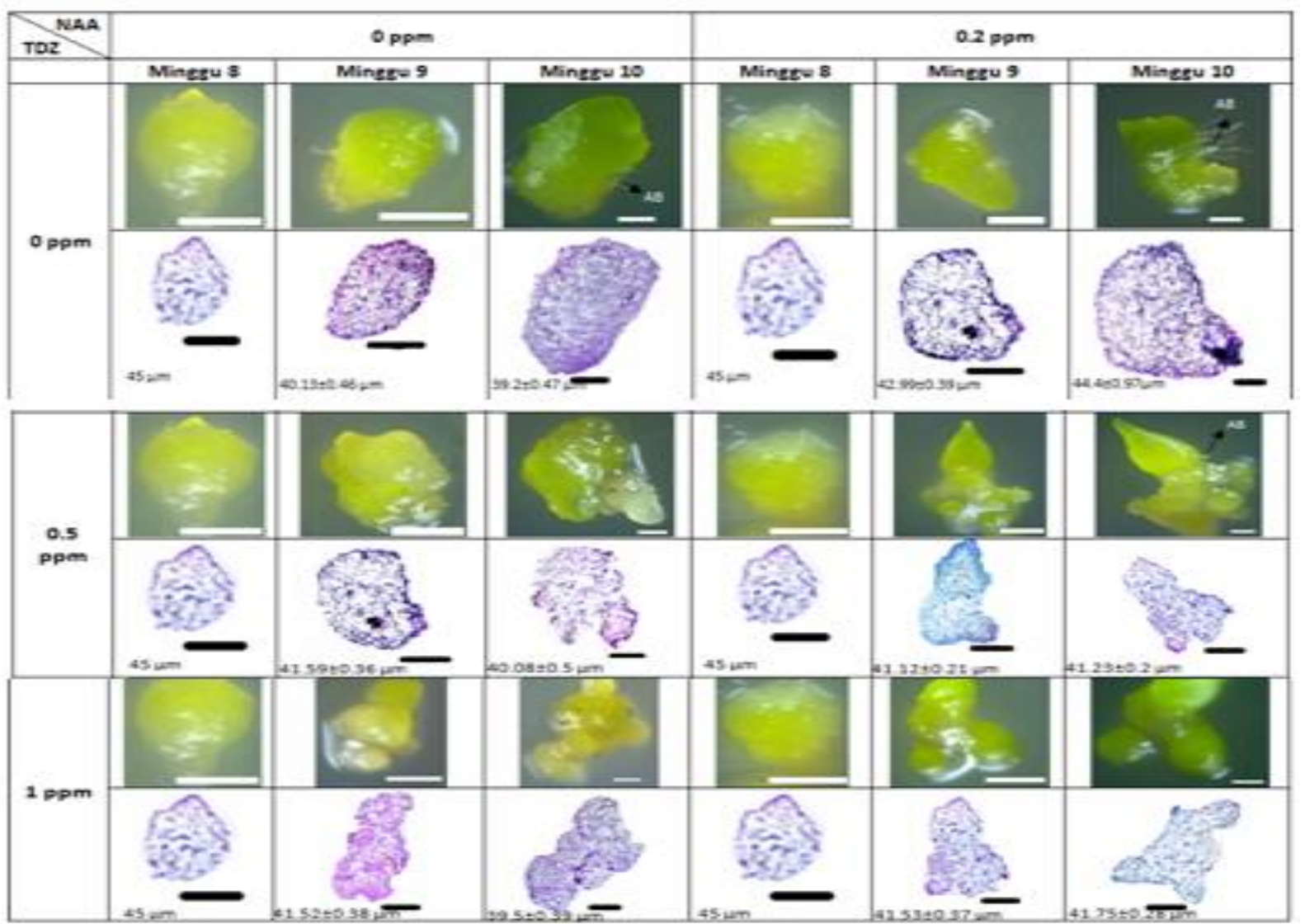

Keterangan $: \mathrm{NAA}=$ Naptalene Acetic Acid $(\mathrm{ppm}), \mathrm{TDZ}=$ Thidiazuron $(\mathrm{ppm})$. Bar Morfologi $=1 \mathrm{~mm}$, Bar Anatomi $=50 \mu \mathrm{m}$.

Persentase pertumbuhan protocorm anggrek $P$. amabilis dalam Tabel 2 pada minggu ke 8-10 hampir mencapai $100 \%$ di berbagai medium perlakuan dengan penambahan konsentrasi ZPT NAA dan TDZ kecuali pada medium dengan konsentrasi NAA:TDZ (0:0.5) ppm dan $(0: 1)$ ppm pada minggu ke-10. Hal ini disebabkan karena adanya kerusakan pada medium sehingga protocorm yang terdapat pada bagian tersebut tidak dapat mengalami pertumbuhan secara optimal.

Tabel 3 menunjukkan perkembangan morfologi dan anatomi protocorm anggrek $P$. amabilis dari minggu ke 8-10. Penambahan NAA dengan konsentrasi $0,2 \mathrm{ppm}$ dapat mempercepat pertumbuhan melalui pembentukan absorbing hair. Absorbing hair merupakan struktur menyerupai rambut yang digunakan oleh eksplan untuk menyerap nutrisi yang ada dilingkungannya. Absorbing hair salah satu parameter yang dapat digunakan untuk mengetahui kecepatan pertumbuhan dari eksplan, pada medium yang sesuai eksplan akan membentuk banyak absorbing hair. Konsentrasi NAA yang lebih tinggi pada eksplan akan membentuk lebih banyak absorbing hair sesuai dengan fungsi senyawa
NAA yaitu mengoptimalkan pertumbuhan dengan menginisiasi pembentukan RAM (Root apical meristem) atau yang biasa disebut sebagai calon akar. Namun, konsentrasi NAA yang terlalu tinggi justru menghambat pertumbuhan karena NAA bekerja pada konsentrasi yang rendah.

Penambahan TDZ dapat menambah ukuran protocorm melalui pembentukan tunas. TDZ merupakan salah satu golongan sitokinin yang banyak diteliti dibidang kultur jaringan untuk mempercepat pembelahan sel. Penambahan TDZ pada konsentrasi yang sesuai dapat meningkatkan proses pertumbuhan pada eksplan melalui pembentukan SAM (Shoot apical meristem) atau tunas. Berdasarkan hasil yang diperoleh (Tabel 3), penambahan TDZ dengan konsentrasi $0.5 \mathrm{ppm}$ dapat menunjukan persentase pembentukan tunas lebih tinggi dibanding kontrol dan konsetrasi lain. Hal ini disebabkan karena TDZ merupakan salah satu fitohormon yang dibutuhkan oleh tanaman dalam konsentrasi yang relatif rendah. Pada konsentrasi yang terlalu tinggi penambahan zat ini dapat menghambat pertumbuhan tanaman dan cenderung tidak berpengaruh. 
Tabel 4. Persentase Protokorm Anggrek P.amabilis yang membentuk Tunas dan Absorbing hair

\begin{tabular}{|c|c|c|c|c|c|}
\hline Medium & $\begin{array}{c}\sum_{\text {protokorm }} \\
\text { yang } \\
\text { diamati }\end{array}$ & $\begin{array}{c}\sum \text { protokorm } \\
\text { yang } \\
\text { membentuk } \\
\text { tunas }\end{array}$ & $\begin{array}{l}\text { Persentase } \\
\text { protokorm } \\
\text { yang } \\
\text { membentuk } \\
\text { tunas } \\
\end{array}$ & $\begin{array}{c}\sum \text { protokorm } \\
\text { yang } \\
\text { membentuk } \\
\text { absorbing hair }\end{array}$ & $\begin{array}{c}\text { Persentase } \\
\text { protokorm yang } \\
\text { membentuk } \\
\text { absorbing hair }\end{array}$ \\
\hline $\mathrm{NP}+\mathrm{N}_{0}+\mathrm{T}_{0}$ & 50 & 12 & $24 \%$ & 5 & $10 \%$ \\
\hline $\mathrm{NP}+\mathrm{N}_{0,2}+\mathrm{T}_{0}$ & 50 & 11 & $22 \%$ & 9 & $18 \%$ \\
\hline $\mathrm{NP}+\mathrm{N}_{0}+\mathrm{T}_{0,5}$ & 50 & 16 & $32 \%$ & 7 & $14 \%$ \\
\hline$N P+N_{0,2}+T_{0,5}$ & 50 & 20 & $40 \%$ & 12 & $24 \%$ \\
\hline $\mathrm{NP}+\mathrm{N}_{0}+\mathrm{T}_{1}$ & 50 & 20 & $40 \%$ & 8 & $16 \%$ \\
\hline $\mathrm{NP}+\mathrm{N}_{0,2}+\mathrm{T}_{1}$ & 50 & 19 & $38 \%$ & 10 & $20 \%$ \\
\hline
\end{tabular}

Keterangan : NP $=$ New Phalaenopsis Medium, $\mathrm{N}=\mathrm{NAA}, \mathrm{T}=\mathrm{TDZ}$

Persentase pembentukan absorbing hair dan tunas paling baik terjadi pada konsentrasi NAA:TDZ $(0,2: 0,5)$ ppm disebabkan karena NAA dan TDZ bekerja secara sinergis dalam memacu pertumbuhan tanaman. Selain itu, konsentrasi TDZ yang optimum berperan penting dalam translokasi dan distribusi NAA serta diakumulasikan pada sel-sel yang memiliki totipotensi tinggi (Murch dan Saxena, 2001). Penambahan NAA tanpa TDZ hanya akan memicu pembentukan absorbing hair. Begitu pula penambahan TDZ tanpa NAA hanya akan memicu pembentukan SAM.

Penambahan NAA dilihat secara anatomi dapat meningkatkan ukuran sel, terutama pemanjangan sel pada konsentrasi rendah. NAA dapat meningkatkan plastisitas dinding sel sehingga sel akan mengalami pembentangan dengan lebih cepat ketika pertumbuhan berlangsung. NAA dapat menginisiasi pemanjangan sel dan memacu protein tertentu yang terdapat pada membran plasma sel tumbuhan untuk memompa ion $\mathrm{H}^{+}$ke dinding sel. Ion $\mathrm{H}^{+}$mengaktifkan enzim tertentu sehingga mampu memutus beberapa ikatan silang hidrogen rantai molekul selulosa penyusun dinding sel. Sel tumbuhan akan memanjang akibat air yang masuk secara osmosis (Wattimena, 1988). Penambahan NAA sebesar 0.2 ppm menyebabkan ukuran sel menjadi lebih panjang pada pengamatan minggu ke-10 dibanding kontrol. Penambahan TDZ dapat meningkatkan pembelahan sel karena TDZ memiliki struktur menyerupai basa nukleotida adenin sebagai salah satu precursor pembelahan sel. Sel yang aktif membelah dicirikan dengan nukleus berukuran besar, sitoplasma berukuran kecil, banyak mengandung amilum, memiliki dinding primer dan lamela yang tipis dengan vakuola kecil.

Parameter yang dapat digunakan untuk mengetahui pengaruh ZPT NAA dan TDZ adalah melalui penyerapan zat warna safranin. Safranin merupakan senyawa chloride yang digunakan dalam pembuatan preparat anatomi maupun histologi organisme. Senyawa ini akan mewarnai inti sel dari sampel yang akan diamati dengan memberikan warna merah. Sel yang aktif membelah akan menunjukkan penyerapan warna yang paling optimal dibandingkan sel yang lain. Hal ini disebabkan karena inti sel yang berukuran besar. Berdasarkan hasil pengamatan preparat anatomi yang telah dilakukan, adanya perbedaan penyerapan warna oleh sel pada bagian apikal, tengah dan basal. Pada medium NP tanpa perlakuan dan preparat anatomi minggu ke-8 sel memiliki intensitas warna yang sama karna sel baru disubkultur dan belum melakukan adaptasi dengan medium yang baru. Sel mulai menunjukkan adanya perbedaan intensitas warna mulai minggu ke- 9 karena sel telah mengalami adaptasi dan telah mengalami pertumbuhan. Pada minggu ke-10 sel bagian basal terpulas lebih gelap dibandingkan sel disekitarnya. Hal tersebut menunjukkan bahwa pada bagian tersebut sel aktif melakukan pembelahan dan diperkirakan selanjutnya sel akan membentuk RAM. Sedangkan pada konsentrasi NAA 0,2 ppm secara umum peningkatan intensitas warna baik pada sel apikal maupun sel basal di minggu ke-9 dan peningkatan intensitas warna paling baik terlihat pada kombinasi NAA dan TDZ $(0,2: 0,5)$ ppm karena sel terpulas paling jelas. Sedangkan untuk penambahan ZPT dari golongan TDZ secara umum dapat terlihat bahwa sel yang mempunyai intensitas warna yang paling baik yaitu sel apikal yang selanjutnya akan menjadi SAM.

\section{Simpulan}

Penambahan kombinasi NAA dan TDZ dapat mempercepat proses pertumbuhan dan perkembangan protocorm anggrek. Kombinasi konsentrasi NAA dan TDZ yang paling optimal dalam meningkatkan pertumbuhan dan perkembangan protocorm anggrek secara morfologi dan anatomi adalah $0,2: 0,5 \mathrm{ppm}$ 


\section{Ucapan Terima Kasih}

Kami mengucapkan terima kasih kepada Dr. Budi Setiadi Daryono, M.Agr.Sc., Dr. rer. nat. Ari

\section{Daftar Referensi}

Bey, Y., Syafii, W., dan Sutrisna. 2006. Pengaruh Pemberian Giberilin (GA3) dan Air Kelapa Terhadap Perkecambahan Bahan Biji Anggrek Bulan (Phalaenopsis amabilis $\mathrm{BL})$ Secara In vitro. Jurnal Biogenesis. 2(2):41-46.

Chugh. S., Guha, S., and Rao, I.U. 2009. Micropropagation of orchids: a review on the potentialof different explants. Sci Hortic, 122(4): 507-520.

Comber, J.B. 1990. Orchids of Java. Charoen Slip Press. Bangkok. pp. 219.

Dressler, R.L. 1993. Phylogeny and classification of the orchid family.Dioscorides Press, Portland, Oregon, USA.

George, E.F and P.D. Sherrington, 1984. Plant propagation by tissue culture. Exegetics Ltd, England. $709 p$

Islam, M.O., Ichihashi. S., and Matsui, S. 1998 Control of growth and development of protokorm like body derived from callus by carbon sources in Phalaenopsis. Plant Biotechnol 15: 183-187.

Iswanto, H. 2002. Petunjuk Perawatan Anggrek. Jakarta : Agromedia Pustaka.

Lu, C., 1993. The use of thidiazuron in tissue culture. In vitro Cell Dev. Biol. 29 : 92-96.

Puspitaningtyas, D.M. 2010. Phalaenopsis amabilis, Bunga Nasional Indonesia. http://pai.or.id/artikel/6-spesies/6phalaenopsis-amabilis-bunga-
Indrianto, S.U., seluruh staf di laboratorium Bioteknologi Fakultas Biologi Universitas Gadjah Mada, dan anggota BiOSC (Biology Orchid Study Club) yang telah membantu selama penelitian.

\section{nasionalindonesia.html. 7 September 2016.}

Razdan, M.K. 2003. Introduction to Plant Tissue Culture. $2^{\text {nd }}$ ed. Science Publishers, Inc. India. P: 71, 72.

Semiarti, E., A. Indrianto, A. Purwantoro, S. Isminingsih, N. Suseno, T. Ishikawa, Y. Yoshioka, Y. Machida, and C. Machida. $2007 . \quad$ Agrobacteriummediated Transformation of The Wild Orchid Species Phalaenopsisamabilis. Plant Biotechnol24 : 265-272.

Sutater, T. dan D.S. Badriah. 1994. Koleksi dan Karakterisasi Anggrek Phalaenopsis amabilis. Bull. Penel. Tan. Hias. 2(1) : 5765

Sutrian, Y. 2004. Pengantar Anatomi TumbuhTunbuhan (Tentang Sel dan Jaringan). Rineka Cipta. Jakarta. Hal.22, 32.

Wattimena G.A. 1988. Peranan kultur Jaringan dalam Mempertinggi Produksi Pertanian di Indonesia. Makalah pada Seminar Kultur Jaringan Tanaman FP. Unibraw, Malang, 24 hal.

Wijayani Y, Solichatun, and W. Mudyantini. 2007. The Shoot Growth And Anatomical Structure Of Protokorm Like Body Of Grammatophyllum Scriptum (Lindl.) Bl. After Kinetin And NAA Application. Bioteknology 4 (2): 33-40.

Zulkarnain. 2009. Kultur Jaringan Tanaman; Solusi Perbanyakan Tanaman Budi Daya. Bumi Aksara, Jakarta. 